\title{
Obtaining prescription drugs in America: it's no bargain
}

\author{
Arthur L. Caplan
}

New York University Langone Medical Center, New York, New York, USA.

J ust about everything related to health care in America costs too much. The validity of that claim rests on what other economically advanced nations pay for the same health services and treatments. The prices of a hospital bed per night, physician salaries, medical devices, surgeries, lab tests, ambulances, and nursing home stays all are more per capita in the United States than they are in Europe, Japan, Australia, New Zealand, or Canada. Despite the across-the-board price disparities, nothing commands the outrage or the political rhetoric in the US more than the price of prescription drugs.

\section{Exorbitant prescription drug prices}

There are many reasons why drug costs dominate current health policy discussions. Patients know that their counterparts in Canada and other nations pay less for drugs, whereas reduced health care costs for other expenses are less widely known. Entrepreneurial vultures have been in the news for their predatory behavior in buying cheap drugs and using monopoly control to extract ridiculously high prices for them. Patients with many serious diseases have taken to the internet to crowdsource for funding for their drugs, often as yet unapproved by the FDA, whose efficacy is unknown, that they or their children cannot afford, giving huge visibility to the high prices they face. Some politicians continue to insist, despite evidence to the contrary, that other nations pay far less to support drug discovery research, giving the American public the false impression that they are getting ripped off by free-loading nations who do not pay their fair share and suggesting that the innovation necessary for new drug development will dry up without tolerating egregious, escalating prices (1). Many point the finger of blame right at the greedy pharmaceutical and biotech industries who continue to launch new treatments for rare diseases, often classified as "orphans," at neverbefore-seen astronomical prices (2). Story after story continues to appear about Americans dying by forgoing necessary drugs due to their tremendous cost or even killing themselves when their bills spiral out of control (3).

Whether any or all of this is true hardly matters. American politicians have shown themselves utterly incapable of doing much of anything to contain drug costs. The pharmaceutical industry's powerful lobbying efforts have enabled it to crush every effort at reform. The Trump administration's rule that would have required drug price disclosures in TV ads has been blocked and is going nowhere (4). Efforts in the Senate to let the Federal Trade Commission go after "patent thicketing" tactics (5) that help shield drugs from generic competition are stalled. Also killed was an idea to allow the FDA to approve cheaper versions of drugs even when a more expensive version was protected by certain patents and blocking companies from suing over patents they did not disclose to the FDA (6). The tax in Obamacare intended to prompt employers to rein in high-cost private plans and force employees to spend more of their own money on their care, a key cost-containment provision of the law, has been rescinded (7). Faced with these setbacks, the Trump administration seems to have retreated back to a tiny redoubt of a cost-containment policy: allowing some drug importation from Canada (8).

\section{Serious solutions to reducing costs}

Morally, Americans in need of drugs deserve affordable access. Aside from permitting mail-order importation from Canada, which

Conflict of interest: The author serves on a scientific advisory board for WIRB-Copernicus Group (WCG). He is a columnist for Medscape/WebMD.

Copyright: @ 2019, American Society for Clinical Investigation.

Reference information: J Clin Invest. 2019;129(11):4558-4559. https://doi.org/10.1172/JCI132977.

would quickly overwhelm Canada (9), are there any serious steps that can be taken to rein in drug costs? Yes, there are.

The single most important step that should be taken is to consolidate all federal drug purchasing under one agency. The best prices that the Veterans Administration and the Department of Defense get for the drugs in their health systems ought to be the same for Medicare, Medicaid, and the Indian Health Service. The federal government should put its enormous bargaining power to use, anchored by the moral reality that drug companies will not want to be seen as creating financial obstacles to drug treatments to the military or veterans, groups with real political clout in Congress (Figure 1). If private insurance companies want to continue to peg their coverage to their own bargaining or to outsource the job to expensive pharmacy benefits management entities (PBMs), they are free to do so and can sell insurance policies accordingly.

Next, the federal payer should begin to link payment to performance. The current market model, in which taxpayers largely fund basic drug research while companies reap enormous financial rewards by picking the winners, continues to be an abject failure. The most promising development opportunities are ultimately handed off to companies with no public return, and companies then barter with for-profit, third-party PBMs that control access and price by cutting nontransparent, sweetheart deals solely to maximize their own returns. Linking payment to performance provides a much-needed incentive that will bring costs down.

Payments to drug companies by all government payers should be linked to outcomes. Pay for performance (P4P), also known as value-based payment, is a promising path for containing drug costs. Britain, Italy, and other nations have achieved much better cost containment by creating systems that should be emulated here.

In Italy, P4P has been in operation since 2006. Centrally managed by Agenzia Italiana del Farmaco (AIFA), it has four types of outcomes-based agreements: (a) 


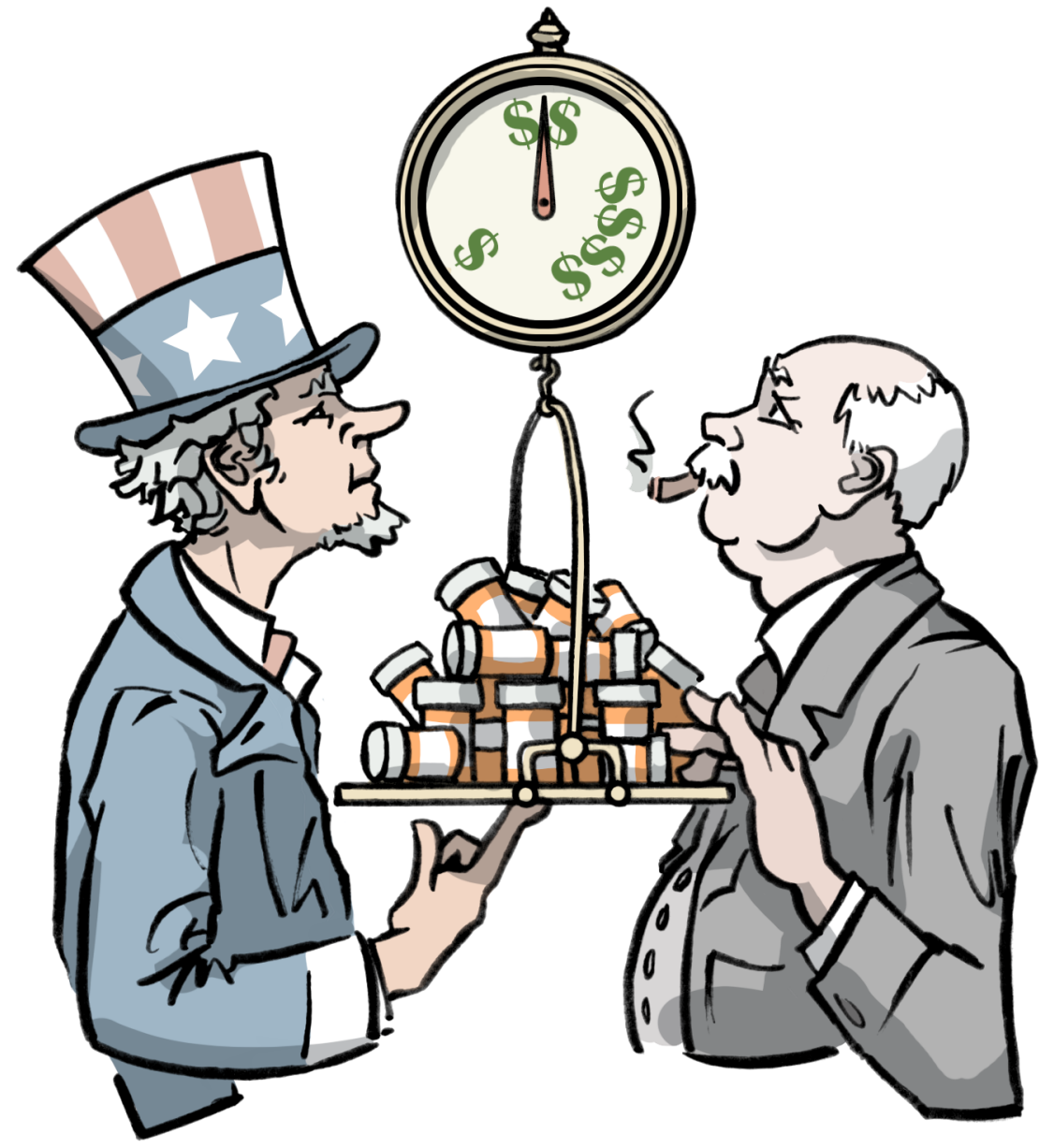

Figure 1. Letting the US government bargain for drug prices could help achieve lower drug costs for Americans. Illustrated by Bruce Worden, after Leslie Thrasher's Tipping the Scales.

cost sharing, for which manufacturers offer a full or partial discount for initial cycles of treatment for eligible patients; (b) risk sharing, for which manufacturers offer partial reimbursement (usually $50 \%$ ) for patients not responding to treatment; (c) payment by results, which requires total reimbursement to the payer by the drug manufacturer for nonresponding patients; and (d) success fee, wherein payment is due only for patients who respond to treatment (10).

Any of these models could be tried for various categories of drugs. Committees that include healthcare experts, patient advocates, and providers could begin the process by debating metrics, outcomes, and quality-of-life considerations to guide payment and price decisions. The P4P strategy can be introduced slowly, but it should ultimately be clear that price and payment for all payers will hinge on drug performance.
Finally, the NIH should institute a program along the lines of the current orphan disease program, with a specific mandate to incentivize drugs that are likely to achieve cost reduction through better efficacy or prevention of disease. There are many details to work out, but the flood of drugs flowing out of the current orphan drug program shows what incentivized research program can do (11). Let's tackle the staggering price tags of new drugs by building cost considerations into the incentive program.

\section{Conclusion}

Health care expenditures in the United States are fueled by out-of-control prices. Politically piecemeal efforts to control drug prices, such as permitting importation of lower priced drugs from nations that have instituted stronger cost-containment measures or improving availability of price information to consumers (who can do absolutely nothing in response to what they learn), are a waste of time and scarce resources. Simply letting government bargain for a best price, linking price to outcome, and incentivizing research to achieve lower health care costs will get Americans what they need: wider access at lower cost.

Address correspondence to: Arthur L. Caplan, Division of Medical Ethics, NYU SOM, 227 East 30th St. 7th floor, New York, New York 10016, USA. Email: arthur. caplan@nyumc.org.

1. Light DW, Caplan AL. Trump blames free riding foreign states for high US drug prices. $B M J$. 2018;360:k1088.

2. Beasley D. Medicare to cover expensive cancer cell therapies. Reuters. August 7, 2019. http://www.reuters.com/article/ health-medicare-cancer/update-1-medicareto-cover-expensive-cancer-cell-therapiesidUSL4N253609. Accessed August 12, 2019.

3. Palmer E. Elderly man who couldn't afford health care kills his wife, then himself. Newsweek. August 9, 2019. http://www.newsweek.com/eldery-mankills-wife-afford-medicl-bills-murder-suicide1453431. Accessed August 12, 2019.

4. Thomas K, Rogers K. Judge blocks trump rule requiring drug companies to list prices in TV ads. New York Times. July 8, 2019. http://www. nytimes.com/2019/07/08/health/drug-pricestv-ads-trump.html. Accessed August 12, 2019.

5. Mukherjee S. Protect at all costs: how the maker of the world's bestselling drug keeps prices sky-high. Fortune. July 18, 2019. http://fortune. com/longform/abbvie-humira-drug-costsinnovation. Accessed August 18, 2019.

6. Fiore K. How pharma beats Washington. Medpage Today. July 17, 2019. http://www. medpagetoday.com/publichealthpolicy/ ethics/81058. Accessed August 12, 2019.

7. Goodnough A. House votes to repeal Obamacare tax once seen as key to health law. New York Times. July 17, 2019. http://www.nytimes.com/ 2019/07/17/us/politics/obamacare-democratscadillac-tax.html. Accessed August 12, 2019.

8. Campbell K. Trump administration's plan to lower healthcare costs. Medpage Today. August 6, 2019. http://www.medpagetoday.com/blogs/campbellsscoop/81446. Accessed August 12, 2019.

9. Florko N, Facher L. Canadians are hopping mad about Trump's drug importation plan. Some of them are trying to stop it. STAT. August 12, 2019. http://www.statnews.com/2019/08/12/ canadians-are-hopping-mad-about-trumpsdrug-importation-plan-some-of-them-aretrying-to-stop-it. Accessed August 12, 2019.

10. Donatini A. The Italian health care system. international health care system profiles. http://international.commonwealthfund.org/countries/ italy. Accessed August 12, 2019

11. Thomas S, Caplan A. The Orphan Drug Act revisited. JAMA. 2019;321(9):833-834. 